\title{
Candida orba sp. nov., a new cactus-specific yeast species from Queensland, Australia
}

\author{
William T. Starmer, ${ }^{1}$ Herman J. Phaff, ${ }^{2}$ Philip F. Ganter ${ }^{3}$ \\ and Marc-André Lachance ${ }^{4}$
}

Author for correspondence: William T. Starmer. Tel: +1 315443 2154. Fax: + 13154432156. e-mail: wstarmer@syr.edu

\footnotetext{
1 Department of Biology, Syracuse University, Syracuse, NY 13244, USA

2 Department of Food Science and Technology, University of California, Davis, CA 95616, USA

3 Biology Department, Tennessee State University, 3500 John Merritt Blvd, Nashville, TN 37209, USA

4 Department of Plant Sciences, University of Western Ontario, London, Ontario, Canada N6A 5B7
}

\begin{abstract}
A new species of yeast from decaying cladodes of Opuntia cactus, Candida orba, is described. This species is a member of a four-species clade of cactophilic yeasts. The new species has only been found in one region of Queensland, Australia, where it was presumably introduced during attempts to eradicate prickly pear cactus. DNA-DNA relatedness, phylogenetic analysis, physiological differences, killer-sensitivity profiles and mating reactions establish the distinctness of the taxon as a new species. $C$. orba is most closely related to Phaffomyces thermotolerans, a species found associated with columnar cacti in the North American Sonoran Desert. The type strain of $C$. orba, isolated from rotting cladodes of Opuntia stricta in the State of Queensland, Australia, is strain UCD-FST 84-833.1 ${ }^{\top}$ ( $=$ CBS $8782^{\top}=$ NRRL $^{Y}$ -

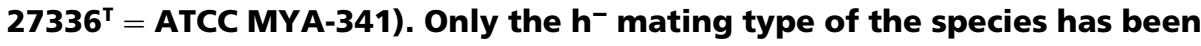
recovered. The lack of the opposite mating type could be the result of a bottleneck during its introduction to Australia. The original geographic/host distribution of this species in the Americas is unknown.
\end{abstract}

Keywords: Candida orba sp. nov., large subunit rDNA analysis, yeasts, DNA-DNA hybridization, phylogeny of Phaffomyces spp.

\section{INTRODUCTION}

Following an extensive survey of yeasts associated with cactophilic Drosophila and their cereoid host plants in the American Sonoran Desert by Heed et al. (1976), an extended survey was made of decaying Opuntia cladode rots in Australia, an as yet unexplored habitat for cactophilic yeasts (Barker et al., 1983, 1984). Starmer et al. (1979) described a new heterothallic yeast, Pichia opuntiae, that was repeatedly isolated from Opuntia necroses in widely separated areas of eastern Australia. These authors also described a closely related yeast found in cereoid cactus rots from various locations in the North American Sonoran Desert, which they named Pichia opuntiae var. thermotolerans, resulting in two varieties of $P$. opuntiae, differing in physiology, habitat and geographic distribution. Subsequently, Holzschu et al. (1985) raised $P$. opuntiae var. thermotolerans to the rank of species based on low DNA relatedness (approx. 28\% between the two varieties), different biogeography and host plants, and differences in

The GenBank accession number for the 26 rDNA D1/D2 sequence of Candida orba UCD-FST $84-833.1^{\top}$ is AF229034. electrophoretic mobilities of 12 metabolic enzymes. Starmer et al. (1984) described another heterothallic species, Pichia antillensis, that was most closely related to $P$. opuntiae (DNA relatedness about $50 \%$ ) and more distantly to Pichia thermotolerans (about $26 \%$ ). Its occurrence in columnar cacti on several islands in the West Indies of the Caribbean Sea separated the three species geographically, by host plant and by a few physiological characteristics, including the production of killer toxins by Pichia antillensis but not by the other two species.

Yamada et al. (1997) reported that $P$. opuntiae and $P$. thermotolerans were only distantly related to Pichia membranifaciens (the type species of the genus Pichia) based on a comparison of partial base sequences of $18 \mathrm{~S}$ rRNA and proposed a new genus, Phaffomyces, for $P$. opuntiae and $P$. thermotolerans. In a subsequent paper, Yamada et al. (1999) also transferred P. antillensis to the genus Phaffomyces based on the complete sequences of 18S rRNA fragments and showed that the genus Phaffomyces is monophyletic and distinct from other ascomycetous genera.

Their conclusions are in agreement with the placement of the above three species in a small clade very distant 
from $P$. membranifaciens by Kurtzman \& Robnett (1998), based on analysis of 26S rRNA partial sequences.

In the present paper, yet another species belonging to the above group is described that has about $50 \%$ DNA relatedness to Phaffomyces thermotolerans and approximately $25 \%$ to both Phaffomyces opuntiae and Phaffomyces antillensis. Currently, 14 strains of this species have been isolated from Opuntia necroses in the State of Queensland, Australia. All of the isolates were found to be of the single mating type $\mathrm{h}^{-}$based on their interaction with the two mating types of $P$. antillensis (see below). The name Candida orba is proposed for the new species, the specific epithet reflecting that currently the species is deprived of its complementary mating type $\mathrm{h}^{+}$.

\section{METHODS}

Strain isolation. Samples of necrotic cactus tissue yielding the new yeast were collected in 1978, 1984 and 1996 from Opuntia species in several locations in Queensland, Australia. The techniques used for yeast isolation have been described by Starmer \& Phaff (1983). Morphological and physiological characteristics of the isolates were determined by methods currently used in yeast taxonomy (Yarrow, 1998). Among the many strains isolated, 14 strains were representative of Candida orba (Table 1).

DNA base composition. Nuclear DNA base composition determination of strains was carried out by the buoyant density method in $\mathrm{CsCl}$ as described by Price et al. (1978).

DNA purification and procedure for reassociation. DNA extraction and purification were carried out by using the methods described by Price et al. (1978) except that the

Table 1 Strain numbers, host plants and locations of C. orba isolates

\begin{tabular}{|lll|}
\hline Strain* & \multicolumn{1}{c|}{ Host plant } & \multicolumn{1}{c|}{ Location $\dagger$} \\
\hline UCD 78-529.3 & Opuntia stricta & Grandchester \\
UCD 84-833.1 & Opuntia stricta & Hemmant \\
UCD 84-837.1 & Drosophila buzzatii & Hemmant \\
UCD 84-860.2 & Opuntia stricta & Hemmant \\
UCD 84-853.3 & Opuntia stricta & Hemmant \\
UCD 84-866.1 & Opuntia stricta & Hemmant \\
UCD 99-1 & Opuntia stricta & Hemmant \\
UCD 99-2 & Opuntia tomentosa & Marburg-Minden \\
UCD 99-3 & Opuntia tomentosa & Brigalow \\
UCD 99-4 & Opuntia tomentosa & Brigalow \\
UCD 99-5 & Opuntia tomentosa & Brigalow \\
UCD 99-6 & Opuntia tomentosa & Brigalow \\
UCD 99-7 & Opuntia tomentosa & Brigalow \\
UCD 99-8 & Opuntia tomentosa & Brigalow \\
\hline
\end{tabular}

* UCD (= UCD-FST), Culture Collection of the Department of Food Science \& Technology, University of California, Davis, CA, USA.

$\dagger$ All locations are in the State of Queensland, Australia.
Table 2 Differences in the physiological abilities of the three Phaffomyces species and C. orba

Species: 1, P. antillensis; 2, P. opuntiae; 3, P. thermotolerans; 4 , C. orba. +, Growth is good under those conditions; 1 (latent), growth is good, but occurs after $7 \mathrm{~d} ; \mathrm{w}$, growth is weak, but not latent; -, no growth occurs; combined symbols, e.g. $1 / \mathrm{w}$, some strains are latent and some strains are weak.

\begin{tabular}{|lcccc|}
\hline Characteristic & $\mathbf{1}$ & $\mathbf{2}$ & $\mathbf{3}$ & $\mathbf{4}$ \\
\hline Cellobiose & - & $1 /-$ & + & + \\
Salicin & - & + & + & + \\
L-Rhamnose & 1 & $1 / \mathrm{w}$ & $1 / \mathrm{w}$ & - \\
D-Mannitol & $1 / \mathrm{w} /-$ & $1 /-$ & 1 & $1 /-$ \\
Citrate & + & + & - & - \\
Cycloheximide $\left(1 \mu \mathrm{g} \mathrm{ml} \mathrm{m}^{-1}\right)$ & + & - & - & - \\
Triterpene glycosides $(2 \%)$ & - & - & - & + \\
at $20^{\circ} \mathrm{C}$ & & & & \\
Triterpene glycosides $(2 \%)$ & - & - & + & + \\
at $30^{\circ} \mathrm{C}$ & & & & \\
$33{ }^{\circ} \mathrm{C}$ & + & $+/-$ & + & + \\
$37{ }^{\circ} \mathrm{C}$ & $+/-$ & - & + & - \\
$39^{\circ} \mathrm{C}$ & $+/-$ & - & - & - \\
\hline
\end{tabular}

purified DNA was concentrated by electrophoresis in a concentrator (ISCO) and the reference DNA was further purified by banding in a $\mathrm{CsCl}$ gradient using a model $\mathrm{L}$ ultracentrifuge prior to labelling with ${ }^{125} \mathrm{I}$ as described by Holzschu et al. (1979). Denaturation of DNA, incubation for reassociation and analysis of the renaturation kinetics, reannealing reactions, and quantification of single- and double-stranded DNAs were done following the protocol of Price et al. (1978). Samples were counted with a gamma ray counter ( $90 \%$ efficiency).

DNA sequence analysis. The D1 and D2 variable domains of the large subunit rDNA were amplified by PCR from whole cells as described by Lachance et al. (1999). The amplified DNA was concentrated and cleaned on Qiaquick PCR columns (Qiagen) and sequenced in an ABI sequencer at the John P. Robarts Research Institute, London, Ontario, Canada. The sequences were edited with the program DNAMAN version 4.0 (Lynnon BioSoft). Existing sequences for other yeasts were retrieved from GenBank, where they had been deposited by Kurtzman \& Robnett (1998). The CLUSTAL W (Thompson et al., 1994) algorithm provided in the DNAMAN package was used to align the sequences and construct a neighbour-joining tree with 1000 bootstrap iterations.

Detection of killer strains. Testing was done according to Starmer et al. (1987). YM (Difco) agar buffered to $\mathrm{pH} 4 \cdot 2$ with $0.05 \mathrm{M}$ citrate buffer and containing $0.003 \%(\mathrm{w} / \mathrm{v})$ methylene blue was the assay medium. Yeast strains to be tested for sensitivity to potential killer strains were spread to a density of approximately $10^{4}$ cells per plate. Potential killer strains were inoculated onto the lawn at high density. Both lawn and test strains were taken from exponentially growing cultures (1-3 d after inoculation). Incubation was done at $22{ }^{\circ} \mathrm{C}$ for $2-3 \mathrm{~d}$. 


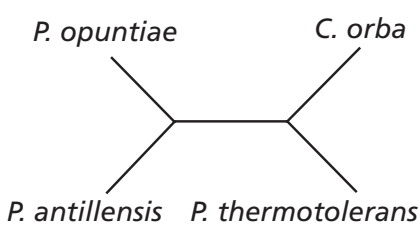

$10 \cdot 0$

DNA distance

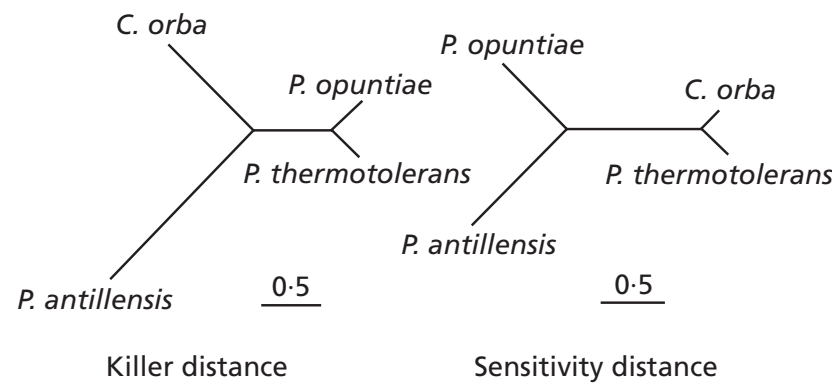

Fig. 1. Dendrograms of the four species relationships based on Euclidean distances: DNA distance [100-relative binding (\%)] physiological distance (data from Table 2), mean taxon responses for killer abilities (rows of Fig. 2) and sensitivity (columns of Fig. 2). Bars, Euclidean distances for each character.

Resistence to triterpene glycosides. Ability of yeasts to grow at $25^{\circ} \mathrm{C}$ in the presence of toxic triterpene glycosides, which are present in cactus species belonging to the subtribe Stenocereinae, was tested in YM agar supplemented with 1 or $2 \%$ dried pulverized tissue of Stenocereus gummosus (agria) (Starmer et al., 1980). The cactus powder may be replaced by $8 \mathrm{mg}$ digitonin $\mathrm{1}^{-1}$ (Sigma).

Distance determination. Comparisons among the four species for DNA relatedness, physiological abilities, killer ability and killer sensitivity were made by calculating distance matrices for each trait and using a least-squares fitting program (FITCH of PHYLIP 3.5c; Felsenstein, 1989) to construct dendrograms. All distances were determined as Euclidean distances. DNA distances between taxa were calculated as $100-$ relative binding $(\%)$ from data in the literature (Starmer et al., 1984; Holzschu et al., 1985) and Table 4. Physiological distance was determined by using Table 2 to assign relative scores $(+=4 ; 1=2 ; \mathrm{w}=1 ;-=$ $0)$ for each trait. In a similar manner, the distance between taxa for killer ability was calculated by assigning relative scores (strong $=3$; moderate killing $=2$; weak killing $=1$; no killing $=0$ ) for the mean within taxon responses given in Fig. 1. Sensitivity to killer toxin was computed by comparing pairs of columns, whereas killer activity was computed by comparing pairs of rows.

\section{RESULTS}

Strains of the new species described here were originally recognized as atypical isolates of Pichia opuntiae that differed phenotypically from that species by their good growth on cellobiose and lack of growth on citrate as sole carbon sources. Table 2 lists the salient physiological differences among the three species of Phaffomyces and C. orba. A dendrogram (unrooted), produced using Euclidean distances based on those physiological differences (Fig. 1) among the four species, shows $C$. orba to be most similar to $P$. thermotolerans, while $P$. opuntiae and $P$. antillensis form another similar pair. All strains of $C$. orba were found to be killer strains of Candida glabrata $(\mathrm{Y}-55=$ NCYC 388; obtained from T. W. Young) in contrast to $P$. opuntiae, which does not kill $C$. glabrata. However, all species of the Phaffomyces clade make mycocins that kill other yeasts and exhibit cross-killing activity. Table 3 lists four strains of each species that were used in reciprocal killer tests. These tests, depicted in Fig. 2, show C. orba is a killer of $P$. opuntiae and $P$. antillensis, but does not kill $P$. thermotolerans.

The proposed transfer of Pichia opuntiae, Pichia thermotolerans and Pichia antillensis to the new genus Phaffomyces by Yamada et al. (1997, 1999) has been accepted in this report. The present paper provides a description of an additional species belonging to this clade, for which the name Candida orba is proposed. The new species has been isolated repeatedly from Opuntia necroses and associated Drosophila in several locations in Queensland, Australia (Table 1). Attempts to obtain sporulation of $C$. orba strains on various sporulation media were unsuccessful. Since all species of Phaffomyces are heterothallic, the $C$. orba strains were mixed in all possible combinations on sporulation media, but no evidence of conjugation or sporulation was found. Mating the strains with mating types of the three Phaffomyces species was attempted and it was found that all strains of $C$. orba produced zygotes on dilute $(25 \%) \mathrm{V}-8$ juice agar with the $\mathrm{h}^{+}$mating strain of $P$. antillensis, but not with the $\mathrm{h}^{-}$mating type of that species. Spores, however, were not observed in the zygotes or in the mixed cultures after extended incubation. Strains of the new species are therefore assigned the mating type $\mathrm{h}^{-}$.

Confirmation of the novelty of $C$. orba was obtained from a DNA hybridization experiment involving ${ }^{125} \mathrm{I}-$ labelled DNA from strain $84-833.1^{\mathrm{T}}$ of $C$. orba and unlabelled DNAs from the species of Phaffomyces. The results, presented in Table 4, clearly show that $C$. orba is distinct from the members of the genus Phaffomyces and represents a new species.

The phylogenetic relationships among members of the genus Phaffomyces and C. orba based on the D1/D2 divergent domains of the large ribosomal subunit are shown in Fig. 3. C. orba exhibited $9.8 \%$ sequence divergence ( 53 base substitutions) from its sister species $P$. thermotolerans, confirming that the two taxa represent related, but distinct evolutionary lineages. $C$. orba differs from $P$. opuntiae and $P$. antillensis by 67 and 70 base substitutions, respectively, in the D1/D2 domain.

\section{Latin description of Candida orba sp. nov.}

In medio liquido cum glucoso, peptono et extracto levedinis (post dies 3 ad $30^{\circ} \mathrm{C}$ ), cellulae ovoideae, elongatae vel clavatae, 2-6×3-10 $\mu \mathrm{m}$, singulae, binae, 
Table 3 Representative strains of the four species used in the cross-killing study, their host source and locality of isolation

\begin{tabular}{|c|c|c|c|}
\hline Species and strain & Designation in Fig. 2 & Host plant & Locality \\
\hline \multicolumn{4}{|l|}{ P. opuntiae } \\
\hline $84-677.2$ & opt-1 & Opuntia stricta & O’Hara, NSW, Australia \\
\hline $84-684.3$ & opt-2 & Opuntia stricta & O’Hara, NSW, Australia \\
\hline $84-869.3$ & opt-3 & Opuntia tomentosa & Warwick, Qld, Australia \\
\hline 84-876.1 & opt-4 & Opuntia tomentosa & Warwick, Qld, Australia \\
\hline \multicolumn{4}{|l|}{ C. orba } \\
\hline $85-1$ & orb-1 & Opuntia stricta & Borallon, Qld, Australia \\
\hline $84-833.1^{\mathrm{T}}$ & orb-2 & Opuntia stricta & Hemmant, Qld, Australia \\
\hline $84-860.2$ & orb-3 & Opuntia stricta & Hemmant, Qld, Australia \\
\hline $84-866.1$ & orb-4 & Opuntia stricta & Hemmant, Qld, Australia \\
\hline \multicolumn{4}{|l|}{ P. antillensis } \\
\hline $82-550 \mathrm{~A}$ & ant-1 & Cephalocereus royenii & Montserrat, Lesser Antilles \\
\hline 82-592B & ant-2 & Cephalocereus royenii & Beef Island, Tortola, BVI \\
\hline $82-589 \mathrm{~B}$ & ant-3 & Cephalocereus royenii & Beef Island, Tortola, BVI \\
\hline $82-568 \mathrm{~B}$ & ant-4 & Cephalocereus royenii & Montserrat, Lesser Antilles \\
\hline \multicolumn{4}{|l|}{ P. thermotolerans } \\
\hline $83-501.1$ & thr-1 & Carnegiea gigantea & Ironwood, Tucson, AZ, USA \\
\hline $83-505.1$ & thr-2 & Carnegiea gigantea & Ironwood, Tucson, AZ, USA \\
\hline $83-510.1$ & thr-3 & Carnegiea gigantea & Ironwood, Tucson, AZ, USA \\
\hline $83-124$ & thr-4 & Stenocereus thurberi & Organpipe Natl Monument, AZ, USA \\
\hline
\end{tabular}

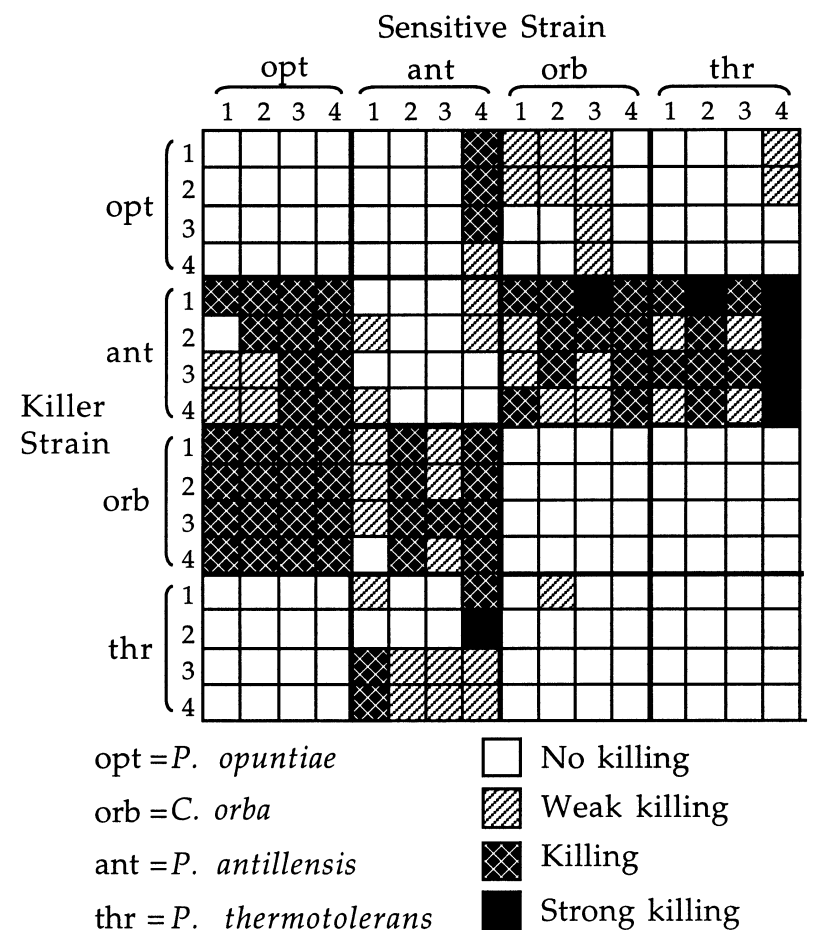

Fig. 2. Cross-killing responses of strains (Table 3 ) of the three Phaffomyces species and C. orba.

gregatim cellularum 6-10, pellicula nulla. Post dies 7 pellicula nitida madita crescit. Cultura in agaro malti (post dies 21 ad $25^{\circ} \mathrm{C}$ ) eburnea, butyrosa vel mollis, convexa, non-patula, glabra cum lineis radiatis, seminitida, margine glabro vel undulato. Cellulae haploideae sexualis solae $h^{-}$. Pseudomycelium in agaro farinae Zea nullum vel rudimentarius. Fermentatio glucosi nullum. Glucosum, cellobiosum, ethanolum, glycerolum, D-glucitolum exigue aut nullum, salicinum, methyl $\beta$-D-glucosidum, glucono- $\delta$-lactonum, acidum lacticum, acidum succinicum, 2-propanolum (exigue), at non galactosum, L-sorbosum, maltosum, saccharosum, trehalosum, lactosum, melibiosum, raffinosum, melezitosum, inulinum, amylum solubile, $D$-xylosum, $L$-arabinosum, D-arabinosum, D-ribosum, $L$-rhamnosum, $i$-erythitolum, ribitolum, galactitolum, D-mannitolum, methyl $\alpha$-D-glucosidum, 2keto-gluconatum, 5-keto-gluconatum, acidum citricum, i-inositolum, methanolum, acidum gluconicum, glucosaminum, $N$-acetyl-glucosaminum, hexadecanum, nec acetonum. Kalium nitricum, natrium nitrosum non assimilantur; ethyl aminum, lysinum, cadaverinum assimilantur. Crescere potest in $30^{\circ} \mathrm{C}$ at non in $37^{\circ} \mathrm{C}$. $\mathrm{G}+\mathrm{C}$ acidi deoxyribonucleati $33.4-34.0 \mathrm{~mol} \% \quad$ (5 stirpes, vide tabulum 4). Ad crescentiam additae vitaminae necessariae sunt. Habitatio in cactis Australiensis. Typus: UCD-FST 84-833. ${ }^{\mathrm{T}} h^{-}$ex tabidosus sacculis cacti Opuntia stricta isolata est. Cultura auxiliaris sexus alterius $h^{+}$carens. In Collectione Zymotica Centraalbureau voor Schimmelcultures, Delphi Batavorum (CBS 8782 $)$ deposita est.

\section{Description of the type strain of Candida orba sp. nov.}

Candida orba (or'ba. L. fem. adj. orba deprived of, indicating loss of its complementary mating type). 
Table 4 Reassociation of ${ }^{125} \mathrm{I}$-labelled nuclear DNA isolated from C. orba $84-833.1^{\top}$ with DNAs of other cactophilic yeast strains

${ }^{125}$ I-labelled DNA $(0 \cdot 2 \mu \mathrm{g})$ and unlabelled DNA $(200 \mu \mathrm{g})$ were incubated at $61 \cdot 5^{\circ} \mathrm{C}$ for $25 \mathrm{~h}$ in $0 \cdot 5 \mathrm{ml} 280 \mathrm{mM}$ phosphate buffer, $\mathrm{pH} 6 \cdot 8$.

\begin{tabular}{|c|c|c|c|}
\hline Organism or tissue & Strain & $\mathbf{G}+\mathbf{C}(\mathbf{m o l} \%)$ & Relative binding (\%) to $84-833 \cdot 1^{\mathrm{T} *}$ \\
\hline C. orba & $84-833.1^{\mathrm{T}}$ & $33 \cdot 6 \pm 0 \cdot 4$ & 100 \\
\hline C. orba & $84-866.1$ & $33 \cdot 5 \pm 0 \cdot 4$ & 103 \\
\hline C. orba & $84-853.3$ & $33 \cdot 4 \pm 0 \cdot 3$ & 102 \\
\hline C. orba & $84-860.2$ & $34 \cdot 0 \pm 0 \cdot 5$ & 100 \\
\hline C. orba & $78-529.3$ & $33 \cdot 7 \pm 0 \cdot 5$ & 100 \\
\hline P. thermotolerans & $76-211^{\mathrm{T}}$ & $33 \cdot 2 \pm 0 \cdot 1$ & 52 \\
\hline P. opuntiae & $77-40^{\mathrm{T}}$ & $33 \cdot 9 \pm 0 \cdot 3$ & 27 \\
\hline P. antillensis & $82-651.1^{\mathrm{T}}$ & $33 \cdot 6 \pm 0 \cdot 6$ & 24 \\
\hline Candida lusitaniae & $80-84$ & $45 \cdot 2 \pm 0 \cdot 1$ & 0 \\
\hline Calf thymus DNA & & & 3 \\
\hline
\end{tabular}

* Corrected for zero-time binding (1.06\%) and for self-reassociation of labelled DNA (4\%) (Price et al., 1978).

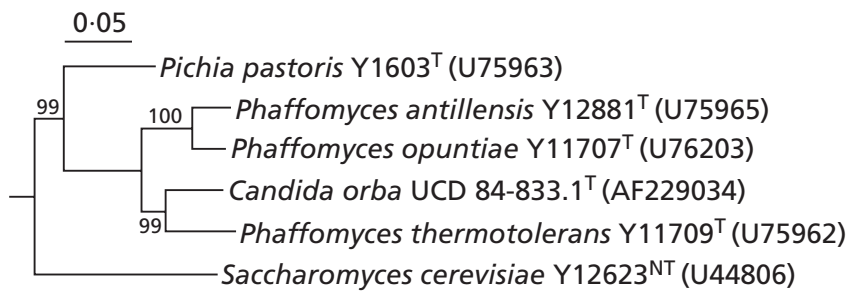

Fig. 3. Neighbour-joining tree showing the phylogenetic placement of $C$. orba based on the sequence of the D1/D2 divergent domains of the large rDNA subunit. The percentage bootstrap values were obtained from 1000 iterations. Bar, $5 \%$ sequence divergence. The sequences for other species were determined by Kurtzman \& Robnett (1998).

In YM (Difco) liquid medium after $3 \mathrm{~d}$ at $30^{\circ} \mathrm{C}$, the cells are ovoid, elongate or club-shaped, $2-6 \times 3-10 \mu \mathrm{m}$, single, in pairs and clusters of $6-10$ cells, reproducing by multilateral budding; a sediment is formed, a pellicle is lacking. After $7 \mathrm{~d}$, a glistening, moist pellicle develops. The streak culture on malt agar after 3 weeks at $25^{\circ} \mathrm{C}$ is cream coloured, butyrous to soft, convex, non-spreading, smooth with slight radial striations, semi-glossy, border smooth to slightly lobulate. On cornmeal agar after 2 weeks, pseudomycelium is absent with occasional rudimentary tufts of growth. Cells are heterothallic but only one mating type has been found $\left(\mathrm{h}^{-}\right)$based on zygote formation with the $\mathrm{h}^{+}$mating type of the related species $P$. antillensis. All of our isolates of $C$. orba reacted in a similar way. Glucose is not fermented. The following carbon compounds are assimilated: glucose, cellobiose, ethanol, glycerol, salicin, methyl $\beta$-D-glucoside, D-mannitol (latent or negative), D-glucitol (weak or negative), glucono- $\delta$-lactone, lactate and succinate. The following are not assimilated: D-galactose, Lsorbose, maltose, sucrose, trehalose, lactose, meli- biose, raffinose, melezitose, inulin, soluble starch, Dxylose, L-arabinose, D-arabinose, D-ribose, L-rhamnose, i-erythritol, ribitol, galactitol, methyl $\alpha$-D-glucoside, 2-keto-D-gluconate, 5-keto-D-gluconate, gluconate, citrate, i-inositol, methanol, D-glucosamine, $\mathrm{N}$ acetyl-D-glucosamine, hexadecane and acetone. Potassium nitrate and sodium nitrite are not utilized as sole sources of nitrogen; ethylamine, cadaverine and Llysine are utilized. Does not grow in vitamin-free medium. Grows in amino acid-free medium. Does not grow in the presence of 100,10 or $1 \mu \mathrm{g}$ cycloheximide $\mathrm{ml}^{-1}$. Weak growth on YM agar containing $5 \% \mathrm{NaCl}$; no growth on YM agar with $7.5 \% \mathrm{NaCl}$. Does not grow in the presence of $50 \%(\mathrm{w} / \mathrm{w})$ glucose. Does not hydrolyse casein or gelatin. Does not produce urease or lipolytic activity. Grows at $30^{\circ} \mathrm{C}$; no growth at $37^{\circ} \mathrm{C}$. Growth is not inhibited at $25^{\circ} \mathrm{C}$ on a complete medium supplemented with $2 \%$ agria cactus powder. Kills standard test strain of Candida glabrata Y-55. Diazonium blue B reaction is negative. Nuclear DNA base composition $33.6 \mathrm{~mol} \%$ (buoyant density method). Habitat: necrotic cladodes of Opuntia stricta in the State of Queensland, Australia. The holotype strain of mating type $\mathrm{h}^{-}$is UCD-FST $84-833.1^{\mathrm{T}}$, which has been deposited in the Centraalbureau voor Schimmelcultures, Delft, The Netherlands, as strain CBS $8782^{\mathrm{T}}$, in the American Type Culture Collection as strain ATCC MYA-341 ${ }^{\mathrm{T}}$ and in the ARS Culture Collection, National Center for Agricultural Utilization Research, Peoria, IL, USA, as NRRL Y$27336^{\mathrm{T}}$. The isotype of mating type $\mathrm{h}^{+}$has not been discovered among the isolates so far recovered.

\section{DISCUSSION}

Explorations in 1978, 1984 and 1996 of the yeast biota associated with Australian Opuntia cactus necroses resulted in the recognition of an additional new species of the recently proposed genus Phaffomyces by 
Yamada et al. (1997, 1999). These authors transferred three cactophilic yeast species previously placed in the genus Pichia into the new genus Phaffomyces as $P$. opuntiae comb. nov., $P$. thermotolerans comb. nov. and $P$. antillensis comb. nov. Fourteen strains (Table 1) of the new species were collected from Opuntia necroses or associated Drosophila buzzatii in the State of Queensland and are described here as Candida orba.

The four species are considered to be distinct species regardless of the species concept one employs: biological species (Mayr, 1963), recognition species (Paterson, 1985), phylogenetic species (Cracraft, 1987) or cohesion species (Templeton, 1989). This is because they: (1) show either pre or post-mating reproductive isolation; (2) live in distinct host species and/or live in distinct geographic regions; and (3) have distinct phenotypes (physiological and DNA-DNA relatedness) that are more similar within a taxon than between taxa.

The cladogram in Fig. 3 confirms the interspecific relationships inferred on the basis of mating compatibility, DNA reassociation and other biological characteristics of Phaffomyces species. It is also in perfect agreement with the phylogeny proposed by Shen \& Lachance (1993) on the basis of restriction maps of the whole rDNA gene cluster (in that paper, C. orba was referred to as 'Hemmant strains'). The observation of a $9.8 \%$ D1/D2 sequence difference between $C$. orba and $P$. thermotolerans is of special interest when contrasted to the DNA reassociation value of $52 \%$. The latter characteristic could be interpreted, in some cases, as a basis to consider such taxa as very close relatives, perhaps even as varieties of the same species. Taken in isolation, a sequence divergence near $10 \%$ would not suggest such a close relationship. These observations suggest that numerical scales of relatedness obtained by various methods should not be regarded as absolutes and that their application in evolutionary taxonomy should always take into account the whole biology of organisms.

Because no sexual interaction was observed by mixing cells of the isolates in all possible combinations, the mating type of the isolates was elucidated from mating attempts with mating types of the three species of Phaffomyces. Although DNA relatedness, physiological similarity and killer-sensitivity profiles (Fig. 2) show that $P$. thermotolerans is most closely related to $C$. orba, mating reactions with that species were unsuccessful because of its very weak intraspecific mating ability (Starmer et al., 1979). However, strong mating, although limited to zygote formation, was observed with the $\mathrm{h}^{+}$mating type of $P$. antillensis, indicating that all isolates of $C$. orba were of mating type $\mathrm{h}^{-}$. In the absence of sporulation, the isolates from Australian Opuntia necroses described here are considered anamorphs and therefore are classified in an anamorphic ascomycetous genus, in this case Candida Berkhout. However, overwhelming evidence, presented in this paper, clearly shows that $C$. orba is a close relative of the other three species of the genus Phaffomyces. In our opinion, placing the new species in the anamorphic genus Candida may create taxonomic confusion, rather than clarifying its taxonomic position as a close relative of its sister species $P$. thermotolerans. Unfortunately, the complementary mating type $\mathrm{h}^{+}$of $C$. orba has not been discovered and therefore, by the International Code of Botanical Nomenclature, the species must be placed in the genus Candida. Unequal distribution of mating types in some habitats has been observed before, such as in the case of Clavispora opuntiae (Phaff et al., 1986). This species also occurs in Australian Opuntia necroses where it was originally discovered. The ratio of mating types of Australian isolates was $150 \mathrm{~h}^{+}$strains to $5 \mathrm{~h}^{-}$strains, the latter occurring in a small area near Borallon in Queensland, whereas the $\mathrm{h}^{+}$strains came from a vast area in eastern Australia. In contrast, the two mating types of C. opuntiae coexist in other parts of the world, occasionally in the same host plant (Lachance et al., 1994). During the prickly pear eradication programme (ca. 1920-1930), infested plants containing the destructive moth, Cactoblastis cactorum, and other insects parasitic on cactus, such as cochineal (Dactilopius opuntiae), were shipped to Australia from both Argentina and various areas in the Southern United States (Dodd, 1940; Murray, 1982). It is speculated that this eradication programme could also be responsible for the observed one-sided mating type distribution of C. orba. The origin of C. orba in the Americas is unknown. However, since $C$. orba is most closely related to $P$. thermotolerans (Table 4 and Fig. 2) and is resistant to triterpene glycosides at $20-30{ }^{\circ} \mathrm{C}$, it is possible that $C$. orba originated in cereoid columnar cacti of the subtribe Stenocereinae rather than in Opuntia of the New World. This might explain its spotty occurrence in Australia.

C. orba can be differentiated from P. opuntiae $(27 \%$ DNA relatedness) by lack of growth on citrate and good growth on cellobiose; it also is a killer of Candida glabrata strain Y-55. It differs from $P$. thermotolerans (52\% DNA relatedness) by host plant, geography, lack of growth at $37^{\circ} \mathrm{C}$ and resistance to triterpene glycosides at $20{ }^{\circ} \mathrm{C}$. It differs from $P$. antillensis $(24 \%$ DNA relatedness) by host plant, geography, good growth on cellobiose and salicin, and lack of growth on citrate. Comparisons of the three taxa of Phaffomyces and $C$. orba by DNA-DNA relatedness, physiology and killer-sensitivity profiles show concordant dendrograms (Fig. 1), indicating the utility of these methods for differentiating species. However, the dendrogram based on killer ability was not concordant and cast doubt on killer profiles as a useful tool to discriminate taxa at this level.

The previously described species of Phaffomyces form a cactus-specific genus most closely related to Pichia (Komagataella) pastoris (Kurtzman \& Robnett, 1998). $P$. pastoris occurs in tree-flux habitats bordering the cactus habitat (Ganter et al., 1986), suggesting a likely origin of this independent cactophilic-yeast genus in a 
tree-flux habitat and presupposing the greater age of the tree-flux habitat.

\section{ACKNOWLEDGEMENTS}

We are indebted to Virginia Aberdeen for her technical assistance and James Haudenshield for his help with the DNA hybridization experiment. Part of this work was supported by a grant from the Natural Science and Engineering Research Council of Canada to M.-A.L.; by a National Institutes of Health Grant S06-GM 08092 to P.F.G.; and by Grants DEB 81-08679 (to W.T.S.) and DEB 81-08898 (to H.J.P.) from the National Science Foundation.

\section{REFERENCES}

Barker, J. F. S., Toll, G. L., East, P. D., Miranda, M. \& Phaff, H. J. (1983). Heterogeneity of the yeast flora in the breeding sites of cactophilic Drosophila. Can J Microbiol 29, 6-14.

Barker, J. F. S., East, P. D., Phaff, H. J. \& Miranda, M. (1984). The ecology of the yeast flora in necrotic Opuntia cacti and of associated Drosophila in Australia. Microb Ecol 10, 379-399.

Cracraft, J. (1987). Species concepts and the ontology of evolution. Biol Philos 2, 63-80.

Dodd, A. P. (1940). The biological campaign against pricklypear. Commonwealth Prickly Pear Board, Government Printer, Brisbane, Queensland, Australia.

Felsenstein, J. (1989). PHYLIP - Phylogeny inference package (version 3.2). Cladistics 5, 164-166.

Ganter, P. F., Starmer, W. T., Lachance, M. A. \& Phaff, H. J. (1986). Yeast communities from host plants and associated Drosophila in southern Arizona: new isolations and analysis of the relative importance of hosts and vectors on community composition. Oecologia 70, 386-392.

Heed, W. B., Starmer, W. T., Miranda, M., Miller, M. W. \& Phaff, H. J. (1976). An analysis of the yeast flora associated with cactiphilic Drosophila and their host plants in the Sonoran Desert and its relation to temperate and tropical associations. Ecology 57, 151-160.

Holzschu, D. L., Presley, H. L., Miranda, M. \& Phaff, H. J. (1979). Identification of Candida lusitaniae as an opportunistic yeast in humans. J Clin Microbiol 10, 202-205.

Holzschu, D. L., Phaff, H. J., Tredick, J. \& Hedgecock, D. (1985). Resolution of the varietal relationship within the species Pichia opuntiae and establishment of a new species, Pichia thermotolerans comb. nov. Int J Syst Bacteriol 35, 457-461.

Kurtzman, C. P. \& Robnett, C. J. (1998). Identification and phylogeny of ascomycetous yeasts from analysis of nuclear large subunit (26S) ribosomal DNA partial sequences. Antonie Leeuwenhoek 73, 331-371.

Lachance, M. A., Nair, P. \& Lo, P. (1994). Mating in the heterothallic haploid yeast Clavispora opuntiae, with special reference to mating type imbalances in local populations. Yeast 10, 895-906.

Lachance, M. A., Bowles, J. M., Starmer, W. T. \& Barker, J. S. F. (1999). Kodamaea kakaduensis and Candida tolerans, two new yeast species from Australian Hibiscus flowers. Can J Microbiol 45, 172-177.
Mayr, E. (1963). Animal species and evolution. Cambridge, MA: Harvard University Press.

Murray, N. D. (1982). Ecology and evolution of Opuntia-Cactoblastis ecosystem in Australia. In Ecological Genetics and Evolution, the Cactus-Yeast-Drosophila System, pp. 17-30. Edited by J. S. F. Barker \& W. T. Starmer. Sydney: Academic Press.

Paterson, H. E. H. (1985). The recognition concept of species. In Species and Speciation, pp. 21-34. Edited by E. S. Vrba. Pretoria: Transvaal Museum Monograph No. 4.

Phaff, H. J., Miranda, M., Starmer, W. T., Tredick, J. \& Barker, J. S. F. (1986). Clavispora opuntiae, a new heterothallic yeast occurring in necrotic tissue of Opuntia species. Int J Syst Bacteriol 36, 372-379.

Price, C. W., Fuson, G. B. \& Phaff, H. J. (1978). Genome comparison in yeast systematics: delimitation of species within the genera Schwanniomyces, Saccharomyces, Debaryomyces and Pichia. Microbiol Rev 42, 161-193.

Shen, R. \& Lachance, M. A. (1993). Phylogenetic study of ribosomal DNA of cactophilic Pichia species by restriction mapping. Yeast 9, 315-330.

Starmer, W. T. \& Phaff, H. J. (1983). Analysis of the community structure of yeasts associated with the decaying stems of cactus. II. Opuntia species. Microb Ecol 9, 247-259.

Starmer, W. T., Phaff, H. J., Miranda, M., Miller, M. W. \& Barker, J. S. F. (1979). Pichia opuntiae, a new heterothallic species of yeast found in decaying cladodes of Opuntia inermis and in necrotic tissue of cereoid cacti. Int J Syst Bacteriol 29, 159-167.

Starmer, W. T., Kircher, H. W. \& Phaff, H. J. (1980). Evolution and speciation of host plant specific yeasts. Evolution 34, 137-146.

Starmer, W. T., Phaff, H. J., Tredick, J., Miranda, M. \& Aberdeen, V. (1984). Pichia antillensis, a new species of yeast associated with necrotic stems of cactus in the lesser Antilles. Int $J$ Syst Bacteriol 34, 350-354.

Starmer, W. T., Ganter, P. F., Aberdeen, V., Lachance, M. A. \& Phaff, H. J. (1987). The ecological role of killer yeasts in natural communities of yeasts. Can J Microbiol 33, 783-796.

Templeton, A. R. (1989). The meaning of species and speciation: a genetic perspective. In Speciation and its Consequences, pp. 3-27. Edited by D. Otte \& J. A. Endler. Sunderland, MA: Sinauer.

Thompson, J. D., Higgins, D. G. \& Gibson, T. J. (1994). CLUSTAL $\mathrm{W}$ : improving the sensitivity of progressive multiple sequence alignment through sequence weighting, position-specific gap penalties and weight matrix choice. Nucleic Acids Res 22, 4673-4680.

Yamada, Y., Higashi, T., Ando, S. \& Mikata, K. (1997). The phylogeny of strains of species of the genus Pichia Hansen (Saccharomycetaceae) based on the partial sequences of $18 \mathrm{~S}$ ribosomal RNA: the proposals of Phaffomyces and Starmera, the new genera. Bull Fac Agric Shizuoka Univ 47, 23-35.

Yamada, Y., Kawasaki, H., Nagatsuka, Y., Mikata, K. \& Seki, T. (1999). The phylogeny of the cactophilic yeasts based on the $18 \mathrm{~S}$ ribosomal RNA gene sequences: the proposals of Phaffomyces antillensis and Starmera caribaea, new combinations. Biosci Biotechnol Biochem 63, 827-832.

Yarrow, D. (1998). Methods for the isolation, maintenance and identification of yeasts. In The Yeasts, a Taxonomic Study, 4th edn, pp. 77-100. Edited by C. P. Kurtzman \& J. W. Fell. Amsterdam: Elsevier. 